\title{
Formulation and Development of Transdermal Patches of Piroxicam
}

\section{Agrahari Saurabh ${ }^{* 1}$, Sharma Atul ${ }^{1}$, Kumar Sachin ${ }^{1}$, Sharma Amit ${ }^{2}$, Sagar Manoj Kumar ${ }^{3}$.}

${ }^{1}$ Department of Pharmaceutics NKBR College of Pharmacy \& Research Centre Meerut U.P.

2 Dept. of Pharmacy Manav Bharti University, Village-Laddo, Sultanpur, Kumarhatti, District Solan, Himachal Pradesh. India

${ }^{3}$ Department of Pharmaceutical chemistry NKBR College of Pharmacy \& Research Centre Meerut U.P.

\begin{abstract}
A B S T R A C T
The aim of the given study was to formation as well as development of patches of piroxicam. Piroxicam basically a steroidal anti-inflammatory drug. Less dosage result in the longer duration of action which make these patches a remarkable in curing the infection for the increase of transdermal properties of the patches various batches were prepared using hydroxyl propyl methyl cellulose, ethyl cellulose and poly vinyl pyrrolidone for best result various parameters are considered like thickness, weight are considered during various test in different batches and the last are i.e. the $6^{\text {th }}$ batch comes good result batch $6^{\text {th }}$ show best evaluation parameter whereas batch $7^{\text {th }}$ show a $95 \%$ release of drug there parameters including moisture content and above mention were tested and were evaluated for best possible result.
\end{abstract}

Key words: Hydroxyl propyl methyl cellulose, ethyl cellulose, poly vinyl pyrrolidone, Piroxicam.

A R T I C L E I N F 0: Received 13 April 2019; Review Completed 25 May 2019; Accepted 31 May 2019; Available online 15 June 2019

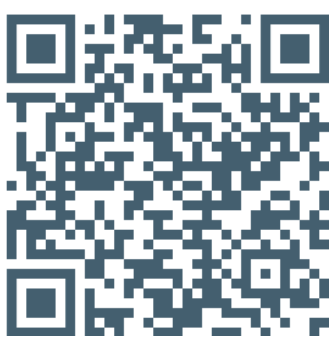

Cite this article as:

Agrahari Saurabh, Sharma Atul, Kumar Sachin, Sharma Amit, Sagar Manoj Kumar, Formulation and Development of Transdermal Patches of Piroxicam, Asian Journal of Pharmaceutical Research and Development. 2019; 7(3): 119-128.

DOI: http://dx.doi.org/10.22270/ajprd.v7i3.511

*Address for Correspondence:

Amit Sharma, Asst. Professor Dept. of Pharmacy Manav Bharti University, Village-Laddo, Sultanpur, Kumarhatti, District Solan, Himachal Pradesh. India

\section{INTRODUCTION}

$\mathrm{T}$ Transdermal drug delivery system is self-contained, discrete dosage form ${ }^{1}$ in which drug stick to the body surface and delivers the drug, across the skin at controlled rate in to the blood stream. TDDS has been a great field of interest in recent times. Many drugs which can be injected directly into the blood stream via skin have been formulated by $\mathrm{TDDS}^{2}$. Transdermal drug delivery system (TDDS) provides a means to sustain drug release as well as reduce the intensity of action and thus reduce the side effects associated with its oral therapy ${ }^{3}$.

\section{Advantages $^{4-7}$}

- Transdermal medication delivers a steady infusion of a drug over an extended period of time.
- An equivalent therapeutic effect can be elicited via transdermal drug input with a lower daily dose of the drug than is necessary, e.g. the drug is given orally.

Disadvantages $^{4-8-9}$

- Many drugs especially drugs with hydrophilic structures permeate the skin too slowly to be of therapeutic benefit.

- The barrier function of the skin changes from one site to another on the same person, from person to person and also with age.

Drug delivery routes across human skin

Drug molecules can penetrate by three pathways:

- Sweat ducts 
- Hair follicles

- Sebaceous glands or directly across the stratum conium.

Factors affecting transdermal drug delivery:-

\section{(A) Physicochemical properties of permeant}

\section{Partition coefficient ${ }^{3}$}

For molecules with intermediate partition coefficient (log $\mathrm{K} 1$ to 3 ) and for highly lipophilic molecules ( $\log \mathrm{K}>3$ ), the intercellular route will be almost the pathway used to traverse the stratum corneum. However, for these molecules a further consideration is the ability to partition out of the stratum corneum into the aqueous viable epidermal tissues. For more hydrophilic molecules (log $\mathrm{K}<1$ ), the transcellular route probably predominates.

\section{Molecular size ${ }^{3}$}

A second major factor in determining the flux of a material through human skin is the size of the molecule. However, for simplicity the molecular weight is generally taken as an approximation of molecular size. It has been suggested that an inverse relationship existed between transdermal flux and molecular weight of the molecule.

\section{Solubility/melting point ${ }^{3}$}

It is well known that most organic materials with high melting points have relatively low aqueous solubility at normal temperature and pressure. The lipophilic molecules tend topermeate through the skin faster than more hydrophilic molecules. However, while lipophilicity is a desired property of transdermal candidates, it is also necessary for the molecule to exhibit some aqueous solubility since topical medicaments are generally applied from an aqueous formulation.

\section{B) Physicochemical properties of the drug delivery system}

\section{Release characteristics ${ }^{7}$}

Solubility of the drug in the vehicle determines the release rate. The mechanism of drug release depends on the following factors:

- Whether the drug molecules are dissolved or suspended in the delivery systems.

- The interfacial partition coefficient of the drug from the delivery system to the skin tissue.

- $\mathrm{pH}$ of the vehicle.

\section{C) Physiological factors}

1. Skin barrier properties in the neonate and young infant

The skin of newborns is known to be relatively susceptible to irritants, other variables related to stratum corneum function such as $\mathrm{pH}$ and stratum corneum hydration may enhance the irritant potential to newborn skin.

\section{Skin barrier properties in aged skin}

There are changes in the physiology of aged skin $(>65$ years). The corneocytes are shown to increase in surface area which may have implications for stratum corneum function due to the resulting decreased volume of intercorneocyte space per unit volume of stratum corneum.

\section{Race $^{3}$}

Racial differences between black and white skins have been shown in some anatomical and physiological functions of the skin although data is relatively sparse. In black skin, increased intracellular cohesion, higher lipid content and higher electrical skin resistance levels compared to whites have been demonstrated.

\section{Skin temperature ${ }^{3}$}

The human body maintains a temperature gradient across the skin from around $37{ }^{\circ} \mathrm{C}$ to around $32{ }^{\circ} \mathrm{C}$ at the outer surface.

\section{COMPONENTS OF TRANSDERMAL PATHCHES:-}

\section{(I) Polymer Matrix1}

The polymer controls the release of the drug from the device. The following criteria should be satisfied for a polymer to be used in transdermal patches.

(a) Molecular weight, chemical functionality of the polymer should be such that the specific drug diffuses properly and gets released through it.

- The polymer should be stable.

- The polymer should be nontoxic

\section{Types of polymer:-}

(a) Natural polymers

(b)Synthetic Elastomers

(c) Synthetic polymers

\section{(II) Drug}

Drug solution in direct contact with release liner.

\section{Physiochemical properties}

1) The drug should have a molecular weight less than 1000 Daltons.

2) The drug should have affinity for both lipophilic and hydrophilic phases.

\section{Biological properties}

a. The drug should be potent with a daily dose of the order of a few $\mathrm{mg} / \mathrm{day}$.

b. The half life $\left(t^{1 / 2}\right)$ of the drug should be short.

c. The drug must not produce allergic response.

\section{(III) Permeation Enhancer}

The flux J. of drug across the skin can be write As

$\mathbf{J}=\mathbf{D} \mathbf{d c} / \mathbf{d x}$

$\mathrm{J}=$ The Flux, $\mathrm{D}=$ diffusion coefficient, $\mathrm{C}=$ Concentration of the diffusing spectes, $\mathrm{X}=$ Spatial coordinate

\section{TYPES OF TRANSDERMAL PATCHES ${ }^{10}$}

\section{Single-layer Drug-in-Adhesive}

The adhesive layer of this system also contains the drug. In this type of patch the adhesive layer not only serves to adhere the various layers together, along with the entire system to the skin, but is also responsible for the releasing of the drug. 


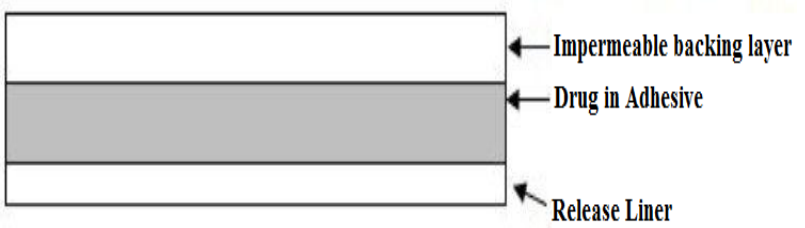

Figure 1: Single layer transdermal patch

\section{Reservoir}

Unlike the Single-layer and Multi-layer Drug-in adhesive systems the reservoir transdermal system has a separate drug layer.

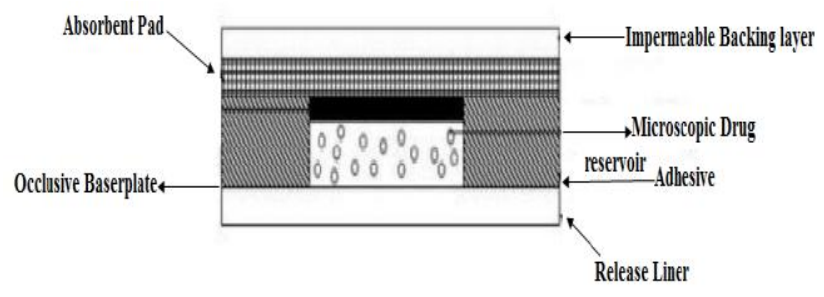

Figure 2: Reservoir transdermal patch

\section{METHODS OF PREPARATION OF TRANSDERMAL PATCHES}

\section{Asymmetric TPX membrane method ${ }^{11}$}

A prototype patch can be fabricated for this a heat sealable polyester film (type $1009,3 \mathrm{~m}$ ) with a concave of $1 \mathrm{~cm}$ diameter will be used as the backing membrane. Drug sample is dispensed into the concave membrane, covered by a TPX \{poly (4-methyl-1-pentene)\} asymmetric membrane, and sealed by an adhesive.

\section{Circular teflonmould method ${ }^{12}$}

Solutions containing polymers in various ratios are used in an organic solvent. Calculated amount of drug is dissolved in half the quantity of same organic solvent. Enhancers in different concentrations are dissolved in the other half of the organic solvent and then added. Di-Nbutylphthalate is added as a plasticizer into drug polymer solution. The total contents are to be stirred for $12 \mathrm{hrs}$ and then poured into a circular teflonmould. The moulds are to be placed on a leveled surface Associate in Nursingd lined with inverted funnel to regulate solvent vaporization in a very streamline flow hood model with an air speed of zero.5 m/s. The solvent is allowed to evaporate for twenty-four hrs. The dried films ar to be keep for one more twenty four hrs at $25 \pm 0.5^{\circ} \mathrm{C}$ in a very desiccators containing colloid before analysis to eliminate aging effects. The kind films ar to be evaluated at intervals one week of their preparation.

\section{Mercury substrate method $^{13}$}

In this method drug is dissolved in polymer solution along with plasticizer. The higher than resolution is to be stirred for 10-quarter-hour to provide an even dispersion and poured in to a leveled mercury surface, lined with inverted funnel to manage solvent evaporation.

\section{By using "IPM membranes" $\operatorname{method}^{14}$}

In this methodology drug is distributed in a very mixture of water and propanediol containing carbomer 940 compound and stirred for twelve hrs in magnetic stirrer. The dispersion is to be neutral and created viscous by the addition of triethanolamine. Buffer $\mathrm{pH}$ scale seven. 4 will be employed in order to get resolution gel, if the drug solubility in solution is extremely poor. The shaped gel are going to be incorporated within the IPM membrane.

\section{By using "EVAC membranes" $\operatorname{method}^{15}$}

In order to prepare the target transdermal therapeutic system, 1\% carbopol reservoir gel, polyethelene (PE), ethylene vinyl acetate copolymer (EVAC) membranes can be used as rate control membranes. If the drug is not soluble in water, propylene glycol is used for the preparation of gel. Drug is dissolved in propylene glycol, carbopol resin will be added to the above solution and neutralized by using $5 \% \mathrm{w} / \mathrm{w}$ sodium hydroxide solution. The drug (in gel form) is placed on a sheet of backing layer covering the specified area. A rate controlling membrane will be placed over the gel and the edges will be sealed by heat to obtain a leak proof device.

\section{Aluminium backed adhesive film method ${ }^{16}$}

Transdermal drug delivery system may produce unstable matrices if the loading dose is greater than $10 \mathrm{mg}$. Aluminium backed adhesive film method is a suitable one. For preparation of same, chloroform is choice of solvent, because most of the drugs as well as adhesive are soluble in chloroform. The drug is dissolved in chloroform and material is going to be additional to the drug answer and dissolved. A custammade aluminum former is lined with foil and also the ends blanked off with tight cork blocks.

\section{Preparation of TDDS by using Proliposomes ${ }^{17-18}$}

The proliposomes area unit ready by carrier technique exploitation film deposition technique. From the soonerreference drug and emulsifier within the quantitative relation of zero.1:2.0 are often used as AN optimized one. The proliposomes area unit ready by taking $5 \mathrm{mg}$ of water pill powder during a one hundred cubic centimeter sphericalbottom flask that is unbroken at $60-70^{\circ} \mathrm{c}$ temperature and also the flask is revolved at 8090 revolutions per minute and dried the water pill at vacuum for half-hour. Once drying, the temperature of the water bat is adjusted to $20-30^{\circ} \mathrm{C}$. Drug and lecithin are dissolved during a appropriate organic solvent mixture, a $0.5 \mathrm{ml}$ aliquot of the organic answer is introduced into the spherical flat-bottom flask at $37^{\circ} \mathrm{C}$, once complete drying second aliquots $(0.5 \mathrm{ml})$ of the answer is to be supplementary. Once the last loading, the flask containing proliposomes area unit connected during a lyophilizer and afterwards drug loaded water pill powders (proliposomes) area unit placed during a desiccator over night then sieved through one hundred mesh. The collected powder is transferred into a glass bottle and keep at the freeze temperature till characterization.

\section{By using free film method ${ }^{19}$}

Free film of cellulose acetate is prepared by casting on mercury surface. A polymer solution $2 \% \mathrm{w} / \mathrm{w}$ is to be prepared by using chloroform. Plasticizers are to be 
incorporated at a concentration of $40 \% \mathrm{w} / \mathrm{w}$ of polymer weight. Five $\mathrm{ml}$ of polymer solution was poured in a glass ring which is placed over the mercury surface in a glass petri dish. The rate of evaporation of the solvent is controlled by placing an inverted funnel over the petri dish. The film formation is noted by observing the mercury surface after complete evaporation of the solvent. The dry film will be separated out and stored between the sheets of wax paper in a desiccator until use. Free films of different thickness can be prepared by changing the volume of the polymer solution.

\section{CHARACTERIZATION OF TRANSDERMAL PATCHES}

\section{Thickness of the patch ${ }^{19-20}$}

The thickness of the drug loaded patch is measured in different points by using a digital micrometer and the average thickness and standard deviation is determined to ensure the thickness of the prepared patch.

\section{Weight uniformity}

The prepared patches are dried at $60^{\circ} \mathrm{c}$ for $4 \mathrm{hrs}$ before testing. A specified area of patch is to be cut in different parts of the patch and weigh in digital balance. The average weight and standard deviation values are to be calculated from the individual weights ${ }^{21}$

\section{Percentage Moisture content}

The prepared films are to be weighed individually and to be kept in a desiccators containing fused calcium chloride at room temperature for $24 \mathrm{hrs}$. After $24 \mathrm{hrs}$ the films are to be reweighed and determine the percentage moisture content from the below mentioned formula ${ }^{[21,23]}$.

\section{$\%$ Moisture content $=$ Initial weight - Final weight $\mathbf{X}$ 100 Final weight}

\section{Content uniformity test}

10 patches are selected and content is determined for individual patches. If 9 out of 10 patches have content between $85 \%$ to $115 \%$ of the specified value and one has content not less than $75 \%$ to $125 \%$ of the specified value, then transdermal patches pass the test of content uniformity. But if 3 patches have content in the range of $75 \%$ to $125 \%$, then additional 20 patches are tested for drug content. If these 20 patches have range from $85 \%$ to $115 \%$, then the transdermal patches pass the test.

\section{MATERIAL AND METHODS:}

Table 1: List of ingredients used and their sources

\begin{tabular}{|l|l|l|}
\hline S. No. & Ingredient & Brand \\
\hline 1 & Drug (Piroxicam) & Idma laboratories Ltd Haryana \\
\hline 2 & PVP & LOBA chem \\
\hline 3 & PEG-400 & S.D. Fine chemical Ltd. \\
\hline 4 & HPMC & LOBA chem. \\
\hline 5 & EC & LOBA chem. \\
\hline 6 & Ethanol & LOBA chem. \\
\hline
\end{tabular}

Table 2: List of Instruments used and their brands

\begin{tabular}{|l|l|l|}
\hline S. No. & Equipment & Brand \\
\hline 1 & Glass wares & Borocil \\
\hline 2 & Melting point apparatus & Almicro \\
\hline 3 & UV Spectrophotometer & Lab India \\
\hline 4 & IR Spectrophotometer & FOPh. J.N.U. \\
\hline
\end{tabular}

\section{Preformulation studies}

Preformulation testing is the first step in the rational development of dosage forms of a drug. It can be defined as an investigation of physical and chemical properties of drug substance, alone and when in combined with excipients. The overall objective of the preformulation testing is to generate information useful to the formulator in developing stable and bioavailability dosage forms which can be mass produced.

The goals of preformulation studies are:

- To establish the necessary physicochemical characteristics of a new drug substance.

- To determine its kinetic release rate profile.

- To establish it's compatibility with different excipients.

\section{Characterization of Piroxicam}

Melting point determination

The melting point of piroxicam was determined by using melting point apparatus with the help of fine capillary.

\section{Spectroscopic studies}

\section{FTIR spectrum interpretation}

The infrared spectrum of the pure piroxicam sample was recorded and the spectral analysis was done. The dry sample of drug was directly placed after mixing and triturating with dry potassium bromide.

\section{UV Analysis}

A standard solution $(10 \mu \mathrm{g} / \mathrm{ml})$ of Piroxicam was prepared in $0.1 \mathrm{M} \mathrm{NaOH}$ and scanned by UV-VIS spectrophotometer (Lab India) between 200 to $400 \mathrm{~nm}$. The $\lambda_{\max }$ was found to be $336 \mathrm{~nm}$.

\section{Construction of calibration curve of piroxicam}

Accurately weighed $10 \mathrm{mg}$ of drug was dissolved in 100 $\mathrm{ml}$ of $0.1 \mathrm{M} \mathrm{NaOH}$ to give a solution of $100 \mu \mathrm{g} / \mathrm{ml}$ concentration. From this solution $1 \mathrm{ml}$ was taken and diluted to $10 \mathrm{ml}$ using $0.1 \mathrm{M} \mathrm{NaOH}$ to get a stock solution of $10 \mu \mathrm{g} / \mathrm{ml}$. From this stock solution various aliquots ranging from $1-10 \mu \mathrm{g} / \mathrm{ml}$ were prepared. The absorbance of these solutions was measured spectrophotometrically at $336 \mathrm{~nm}$ against reference blank.

\section{Determination of solubility of Pirocxicam}

Piroxicam solubility was determined in distilled water and phosphate buffer. The procedure can be detailed as follows:- in small glass vials solvent was taken and solubility was determined by making saturated solution of drug the drug was gradually added till the solutions turned cloudy indicating the presence of undissolved drug the solutions were kept at rest for $24 \mathrm{hrs}$ to assist the attainment of equilibrium with undissolved drug particles the supernatants were decanted and filtered through filter paper the filtrates were suitably diluted and the absorbance were measured at $336 \mathrm{~nm}$.

\section{Partition coefficient}

The partition coefficient of the drug was determined by shaking equal volumes of oil and aqueous phases in a separating funnel drug solution of $1 \mathrm{mg} / \mathrm{ml}$ was prepared in octanol, $50 \mathrm{ml}$ of this solution was taken in a separating funnel and shaken with an equal volume of distilled water for 10 minutes and allowed to stand for 1hour.Then the oil 
phase was assayed before and after partitioning using UV spectroscopy.

\section{Formulation of Transdermal Patches}

Transdermal patches of piroxicam were prepared by solvent casting technique. Ethanolic solution of polymer and drug along with polyethylene glycol (plasticizer) was prepared. The homogenous mixture was poured into plastic mould. The solvent was allowed to evaporate at controlled rate by placing an inverted funnel over the plastic mould. The control of evaporation is necessary for uniform drying of films. The drying was carried out at room temperature for duration of 24 hours. After 24 hours the dry films was removed from plastic mould and stored in desiccators until used.

Table 3: Composition of different transdermal patches prepared by solvent casting method.

\begin{tabular}{|c|c|c|c|c|c|c|c|}
\hline $\begin{array}{l}\text { Formulation } \\
\text { Code }\end{array}$ & $\begin{array}{l}\text { Piroxicam } \\
\text { (mg) }\end{array}$ & $\begin{array}{l}\text { Polymer } \\
\text { Combination }\end{array}$ & $\begin{array}{l}\text { Polymer } \\
\text { Ratio }\end{array}$ & $\begin{array}{l}\text { Permeation enhancer } \\
\text { (Oleic acid) }\end{array}$ & \multicolumn{2}{|c|}{ Plasticizer } & Solvent \\
\hline F1 & 100 & EC:PVP & $1.0: 0.5$ & $0.5 \%$ & $0.5 \%$ & - & Ethanol \\
\hline $\mathrm{F} 2$ & 100 & EC:PVP & $0.5: 1.0$ & $0.5 \%$ & $0.5 \%$ & - & Ethanol \\
\hline F3 & 100 & EC:PVP & $1.0: 1.0$ & $0.5 \%$ & $1.0 \%$ & - & Ethanol \\
\hline F5 & 100 & HPMC:PVP & $0.5: 1.0$ & $0.5 \%$ & - & $0.5 \%$ & Ethanol \\
\hline F6 & 100 & HPMC:PVP & $1.0: 1.0$ & $0.5 \%$ & - & $1.0 \%$ & Ethanol \\
\hline F7 & 100 & HPMC:EC:PVP & $1.0: 1: 1$ & $0.5 \%$ & - & $1.0 \%$ & Ethanol \\
\hline
\end{tabular}

\section{Evaluation of Transdermal Patches}

\section{Physical appearance}

The prepared patches were physically examined for colour, clarity and surface texture.

\section{Thickness of the patch}

The thickness of the drug loaded patch was measured in different points by using a digital micrometer and determines the average thickness and standard deviation for the same to ensure the thickness of the prepared patch.

\section{Weight uniformity}

The prepared patches were dried at $60^{\circ} \mathrm{c}$ for $4 \mathrm{hrs}$ before testing. A specified area of patch was cut in different parts of the patch and weigh in digital balance. The average weight and standard deviation values are to be calculated from the individual weight.

\section{Folding endurance}

A strip of specific area was cut evenly and repeatedly folded at the same place till it broke. The number of times the film could be folded at the same place without breaking gave the value of the folding endurance .

\section{Percentage Moisture content}

The prepared films were weighed individually and to be kept in a desiccators containing fused calcium chloride at room temperature for $24 \mathrm{hrs}$. After $24 \mathrm{hrs}$ the films are to be reweighed and determine the percentage moisture content from the below mentioned formula.

$$
\text { Moisture content }(\%)=\frac{\text { Initial weight }- \text { Final weight }}{\text { Final weight }} \times 100
$$

\section{Percentage Moisture uptake}

The weighed films were kept in desiccators at room temperature for $24 \mathrm{hrs}$ containing saturated solution of potassium chloride in order to maintain $84 \%$ RH. After $24 \mathrm{hrs}$ the films are to be reweighed and determine the percentage moisture uptake from the below mentioned formula.

\section{Water vapor permeability}

Glass vials of $5 \mathrm{ml}$ capacity were washed thoroughly and dried to a constant weight in an oven. About $1 \mathrm{gm}$ of fused Calcium chloride was taken in the vials $\&$ the polymer films were fixed over the brim with the help of an adhesive tape. Then the vials were weighed and stored in a humidity chamber at $85 \% \mathrm{RH}$ condition for a period of 24 hours. The vials were removed and weighed at various time intervals like $3,6,12,18$ and 24 hrs to note down the weight gain.

\section{Drug content}

A specified area of patch was dissolved in a suitable solvent in specific volume. Then the solution is to be filtered through a filter medium and analyze the drug contain with the suitable method (UV or HPLC technique).

\section{Percentage Elongation break test}

The percentage elongation break was determined by noting the length just before the break point, the percentage elongation can be determined from the below mentioned formula.

$$
\text { Elongation }(\%)=\frac{\text { Final length of the strip }- \text { Initial length of the strip }}{\text { Initial length of the strip }} \times 100
$$

\section{Result:-}

Formulations of Piroxicam transdermal patches were formulated using different polymer ratios. The prepared formulations are shown in figure. The formulations are subjected to evaluation parameters like thickness, drug content, folding endurance, tensile strength, percentage elongation, percentage moisture absorption, FTIR studies. 


\section{FTIR study}

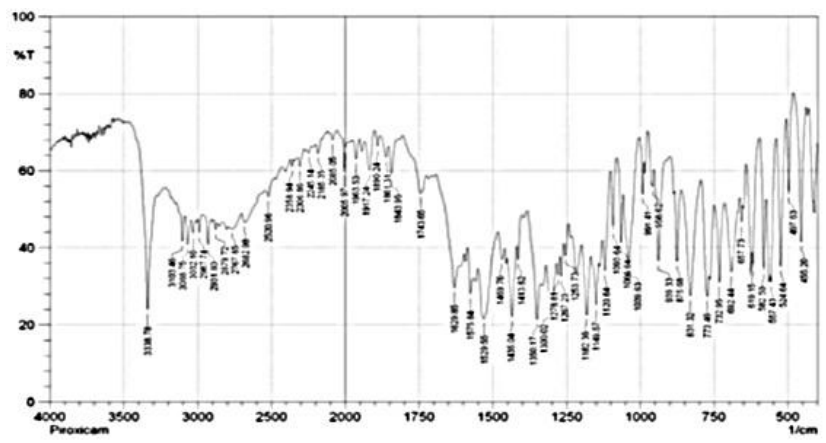

Figure 3: FTIR Spectroscopy of Piroxicam

The FTIR spectra of piroxicam is shown in fig. 5.1., the main characteristic peak of piroxicam was the secondary amine N-H stretching which appeared at $3338 \mathrm{~cm}^{-1}$. It has been reported that piroxicam has two inter convertible crystalline forms, namely the needle and cubic forms. The IR absorption peaks at $1634 \mathrm{~cm}^{-1}$ and $1629 \mathrm{~cm}^{-1}$ are assigned to the stretching of the amide carbonyl groups of the needle form and the cubic form respectively, the peak at $1529 \mathrm{~cm}^{-1}$ is due to the stretching of the second amide band for both crystalline forms of piroxicam. In the present study, the peak at $1629.55 \mathrm{~cm}^{-1}$ was found in the IR spectrum of piroxicam, suggesting that the cubic form of piroxicam was used.

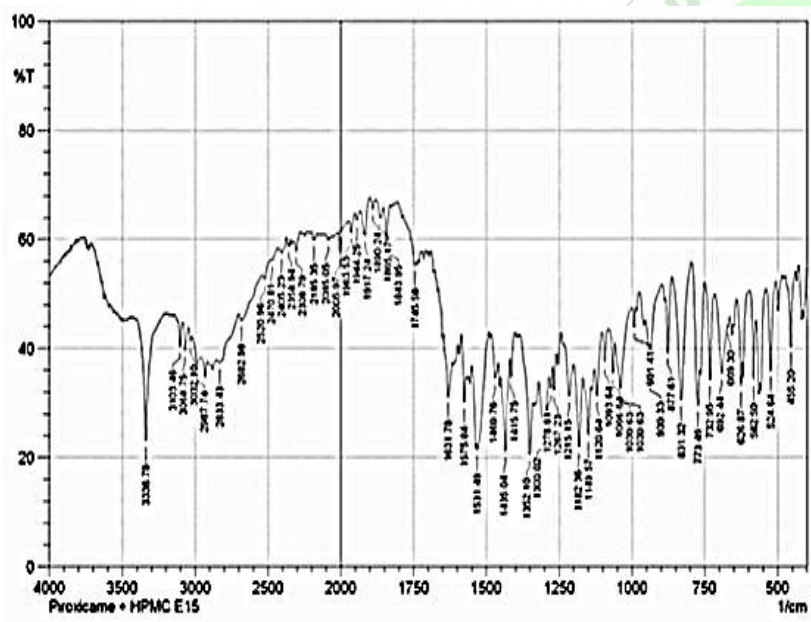

Figure 4: FTIR of Piroxicam + Hydroxy propyl methyl cellulose (HPMC)

The PIR (Piroxicam Infrared Spectra) also exhibited other characteristic peaks like, $\mathrm{C}=\mathrm{N}$ stretching vibration of pyridyl nitrogen assigned at $1577.49 \mathrm{~cm}^{-1}, \mathrm{C}=\mathrm{C}$ stretching of pyridine ring at $1531.2 \mathrm{~cm}^{-1}, \mathrm{C}=\mathrm{C}$ stretching of aromatic ring at $1434.78 \mathrm{~cm}^{-1}, \mathrm{C}-\mathrm{N}$ stretching at 1349.79 $\mathrm{cm}^{-1}, \mathrm{C}-\mathrm{O}$ stretching at $1214.93 \mathrm{~cm}^{-1}, \mathrm{~S}(=\mathrm{O}) 2$ stretching at $1149.37 \mathrm{~cm}^{-1},-\mathrm{SO}_{2}-\mathrm{N}$ stretching at $1064 \mathrm{~cm}^{-1}$, aromatic $\mathrm{CH}$ bending at $875.52 \mathrm{~cm}^{-1}$, ortho-disubstituted phenyl at $773.89 \mathrm{~cm}^{-1}$ and C-S stretching at $690.39 \mathrm{~cm}^{-1}[49,50]$. HPMC fig. 5.2 .showed an ester $\mathrm{C}=\mathrm{O}$ stretching peak around $1724 \mathrm{~cm}^{-1}$. The pattern of the selected transdermal formula showed band at $3336.88 \mathrm{~cm}^{-1}$, which was related to the N-H stretching and all the original peaks of the pure drug remained without changing, the existence of 1629 $\mathrm{cm}^{-1}$ indicates that the piroxicam was fixed in the cubic polymorphic form and no interaction with accidents occurred. Specific changes in IR spectra are not very clear. This could be due to variations in the resonance structure, rotation of a part of a molecule or certain bond, so it was can concluded that there is no interaction between piroxicam: HPMC:PVP:EC after evaporation of the solvent

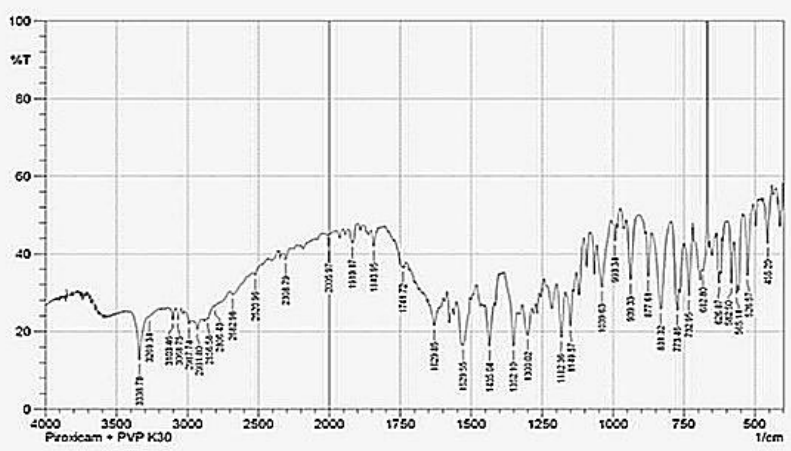

Figure 5: FTIR of piroxicam + Poly vinyl pyrrolidone (PVP)

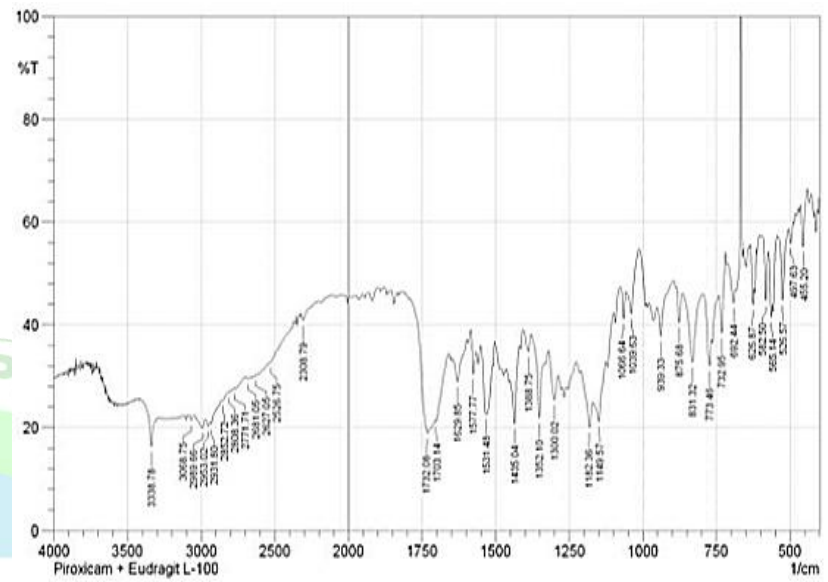

Figure 6: FTIR of piroxicam + Poly vinyl pyrrolidone + Ethyl cellulose + Hydroxy propyl methyl cellulose.

\section{Determination of $\lambda_{\max }$}

A standard solution $(10 \mu \mathrm{g} / \mathrm{ml})$ of Piroxicam was prepared in $0.1 \mathrm{M} \mathrm{NaOH}$ and scanned by UV-VIS spectrophotometer (Lab India) between 200 to $400 \mathrm{~nm}$. The $\lambda_{\max }$ Was found to be 336 nmthe spectrum.

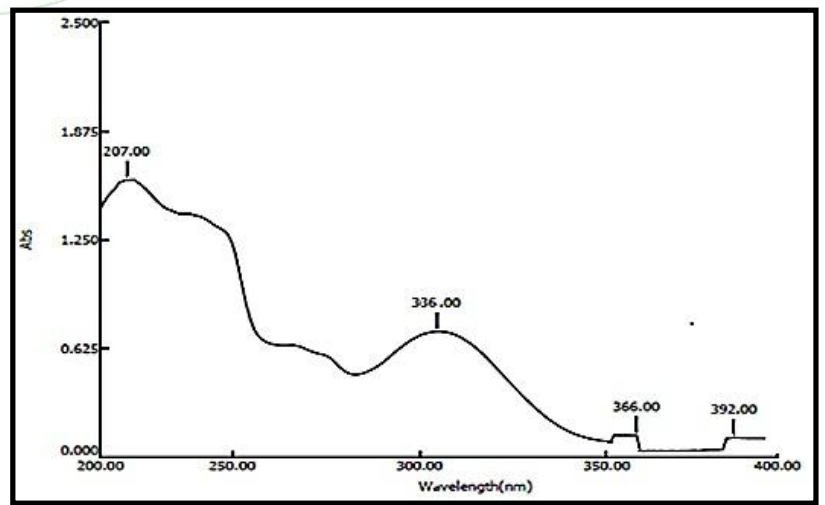

Figure 7: UV spectrum of piroxicam

\section{Calibration curve of Piroxicam}

Accurately weighed $10 \mathrm{mg}$ of drug was dissolved in 100 $\mathrm{ml}$ of $0.1 \mathrm{M} \mathrm{NaOH}$ to give a solution of $100 \mu \mathrm{g} / \mathrm{ml}$ concentration. From this solution $1 \mathrm{ml}$ was taken and diluted to $10 \mathrm{ml}$ using $0.1 \mathrm{M} \mathrm{NaOH}$ to get a stock solution of $10 \mu \mathrm{g} / \mathrm{ml}$. From this stock solution various aliquots ranging from 1-10 $\mu \mathrm{g} / \mathrm{ml}$ were prepared. The absorbance of these solutions was measured spectrophotometrically at $336 \mathrm{~nm}$ against reference blank. Piroxicam was found to obey Beer-Lambert's law in the concentration range of 0- 
$14 \mu \mathrm{g} / \mathrm{ml}$ with regression coefficient $\left(\mathrm{r}^{2}\right)$ value 0.994 the regression equation was calculated as $\mathrm{y}=0.009 \mathrm{x}-0.004$ in $0.1 \mathrm{M} \mathrm{NaOH}$.

Table 4: Calibration curve of piroxicam in $\mathrm{pH} 7.4$ phosphate buffer solution

\begin{tabular}{|l|l|}
\hline Concentration $\boldsymbol{\mu g} / \mathbf{~ m l}$ & Absorbance at 336 $\mathbf{~ m}$ \\
\hline 0 & 0.000 \\
\hline 2 & 0.172 \\
\hline 4 & 0.328 \\
\hline 6 & 0.509 \\
\hline 8 & 0.660 \\
\hline 10 & 0.818 \\
\hline 12 & 0.976 \\
\hline 14 & 1.120 \\
\hline 16 & 1.126 \\
\hline
\end{tabular}

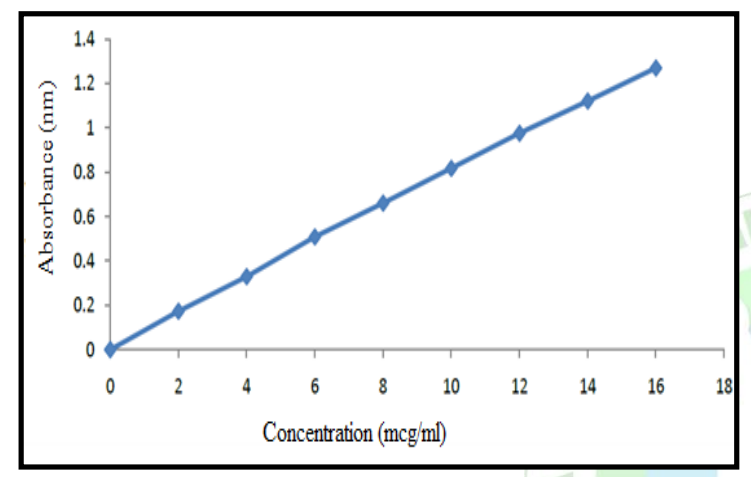

Figure 8: Calibration curve of Piroxicam in $\mathrm{pH} 7.4$ buffer

\section{Solubility studies}

The solubility of different formulation in water and $\mathrm{pH}$ 7.4 phosphate buffer was determined. Excess quantities of prepared formulation were taken into screw- capped $50 \mathrm{ml}$ glass vials filled with water and $\mathrm{pH} 7.4$ phosphate buffer. The vials were shaken for 24 hours on mechanical shaker. The solution was filtered through Whatmann filter paper and the drug concentration was determined spectrophotometrically.

Table 5: Solubility data for piroxicam

\begin{tabular}{|l|l|}
\hline Solubility medium & Solubility $(\mathbf{m g} / \mathbf{m l})$ \\
\hline Water & $0.143 \mathrm{mg} / \mathrm{ml}$ \\
\hline PEG 600 & $9.438 \mathrm{mg} / \mathrm{ml}$ \\
\hline Propylene Glycol & $2.562 \mathrm{mg} / \mathrm{ml}$ \\
\hline
\end{tabular}

\section{Physical evaluation}

\section{Thickness}

The thickness of the Patches varied from $0.42 \pm 0.31$ to $0.45 \pm 0.86 \mathrm{~mm}$. The values obtained for all the formulations.

\section{Moisture absorption}

The \% moisture absorption was in the range of $2.46 \pm$ 0.29 to $4.73 \pm 0.22$ and $4.14 \pm 0.68$ to $5.59 \pm 0.17$ at $75 \%$ $\mathrm{RH}$ and $85 \% \mathrm{RH}$, respectively.

\section{Moisture content}

The moisture content of the formulation ranges from 2.13 \pm 0.39 to $3.42 \pm 0.21$. The value for the moisture content.

\section{Folding Endurance}

The folding endurance was found to be in the range of $>100$. This data revealed that the patches had good mechanical strength along with flexibility the values for all the formulation is tabulated.

\section{Weight variation}

The weight variation was to be in the range of $160.33 \pm$ 0.47 to $161.33 \pm 0.95$. The values for all the formulations are tabulated.

\section{Drug content}

The drug content was in the range of $94.57 \pm 0.36$ to 97.58 \pm 0.85 .

Table 6: Results of various evaluation parameters of the prepared transdermal patches.

\begin{tabular}{|l|l|l|l|l|}
\hline Formulation code & Weight variation (mg) & Thickness (um ) & Drug Content (\%) & Flatness \% \\
\hline F1 & $160.64 \pm 0.92$ & $0.43 \pm 0.22$ & $94.57 \pm 0.36$ & 100 \\
\hline F2 & $161.03 \pm 0.83$ & $0.42 \pm 0.31$ & $95.11 \pm 0.28$ & 100 \\
\hline F3 & $160.33 \pm 0.47$ & $0.44 \pm 0.95$ & $95.24 \pm 0.38$ & 100 \\
\hline F4 & $160.66 \pm 0.94$ & $0.45 \pm 0.33$ & $96.35 \pm 0.28$ & 100 \\
\hline F5 & $160.33 \pm 0.48$ & $0.43 \pm 0.88$ & $95.64 \pm 0.45$ & 100 \\
\hline F6 & $160.66 \pm 0.96$ & $0.42 \pm 0.94$ & $97.58 \pm 0.85$ & 100 \\
\hline F7 & $161.33 \pm 0.95$ & $0.45 \pm 0.86$ & $96.45 \pm 0.27$ & 100 \\
\hline F8 & $160.66 \pm 0.93$ & $0.45 \pm 0.75$ & $95.63 \pm 0.76$ & 100 \\
\hline
\end{tabular}


Table 7: Results of various evaluation parameters of the prepared transdermal patches.

\begin{tabular}{|c|c|c|c|c|c|c|}
\hline \multirow{2}{*}{$\begin{array}{l}\text { Formulation } \\
\text { code }\end{array}$} & \multirow{2}{*}{$\begin{array}{l}\text { Tensile strength } \\
(\mathrm{N} / \mathrm{mm} 2)\end{array}$} & \multirow{2}{*}{$\begin{array}{l}\text { Folding } \\
\text { endurance }\end{array}$} & \multirow[t]{2}{*}{ MVTR( \%) } & \multirow{2}{*}{$\begin{array}{l}\text { Moisture } \\
\text { content }(\%)\end{array}$} & \multicolumn{2}{|c|}{ Moisture Absorption (\%) } \\
\hline & & & & & $75 \%$ RH & $85 \%$ RH \\
\hline F1 & $5.12 \pm 0.580$ & $138 \pm 1.05$ & $2.35 \pm 0.42$ & $3.42 \pm 0.21$ & $2.46 \pm 0.29$ & $4.36 \pm 0.24$ \\
\hline $\mathrm{F} 2$ & $5.48 \pm 0.255$ & $135 \pm 1.49$ & $1.45 \pm 0.32$ & $2.37 \pm 0.35$ & $3.32 \pm 0.71$ & $5.19 \pm 0.41$ \\
\hline F3 & $5.50 \pm 0.200$ & $128 \pm 1.69$ & $1.21 \pm 0.19$ & $2.51 \pm 0.29$ & $3.79 \pm 0.23$ & $5.38 \pm 0.53$ \\
\hline $\mathrm{F} 4$ & $5.56 \pm 0.070$ & $122 \pm 1.69$ & $1.48 \pm 0.32$ & $2.13 \pm 0.39$ & $4.03 \pm 0.45$ & $5.51 \pm 0.49$ \\
\hline F5 & $5.57 \pm 0.265$ & $119 \pm 1.26$ & $2.34 \pm 0.44$ & $2.47 \pm 0.51$ & $4.23 \pm 0.13$ & $5.72 \pm 0.15$ \\
\hline F6 & $5.44 \pm 0.202$ & $118 \pm 1.92$ & $2.12 \pm 0.76$ & $2.41 \pm 0.28$ & $3.08 \pm 0.32$ & $4.14 \pm 0.68$ \\
\hline F7 & $5.48 \pm 0.133$ & $112 \pm 1.05$ & $2.63 \pm 0.23$ & $3.36 \pm 0.42$ & $4.55 \pm 0.17$ & $5.59 \pm 0.17$ \\
\hline F8 & $5.42 \pm 0.212$ & $109 \pm 1.49$ & $2.38 \pm 0.62$ & $2.45 \pm 0.33$ & $4.73 \pm 0.22$ & $5.25 \pm 0.29$ \\
\hline
\end{tabular}

\section{In- Vitro Studies}

Table 8: The In vitro studies data of formulation of piroxicam.

\begin{tabular}{|c|c|c|c|c|c|c|c|c|}
\hline \multirow[t]{2}{*}{ Formulation } & \multicolumn{8}{|l|}{ Time (min) } \\
\hline & 15 & 30 & 45 & 60 & 120 & 180 & 240 & 360 \\
\hline F1 & $3.85 \pm 2.57$ & $7.18 \pm 2.52$ & $10.73 \pm 2.0$ & $15.35 \pm 2.4$ & $19.23 \pm 2.0$ & $23.60 \pm 2.58$ & $27.99 \pm 2.66$ & $36.31 \pm 2.13$ \\
\hline F2 & $11.58 \pm 4.39$ & $17.50 \pm 3.5$ & $27.74 \pm 5.7$ & $34.78 \pm 4.5$ & $40.30 \pm 3.2$ & $46.00 \pm 3.96$ & $54.16 \pm 4.41$ & $36.35 \pm 3.33$ \\
\hline F3 & $1.27 \pm 3.01$ & $3.75 \pm 3.63$ & $6.30 \pm 3.48$ & $8.304 \pm 4.8$ & $11.08 \pm 4.2$ & $14.18 \pm 3.87$ & $21.86 \pm 2.58$ & $36.31 \pm 0.88$ \\
\hline F4 & $6.41 \pm 1.39$ & $12.81 \pm 1.2$ & $21.66 \pm 2.1$ & $31.51 \mathrm{~V} 1.7$ & $38.26 \pm 1.8$ & $47.60 \pm 1.96$ & $56.30 \pm 2.42$ & $36.31 \pm 1.57$ \\
\hline F5 & $3.22 \pm 1.36$ & $4.74 \pm 1.96$ & $6.86 \pm 2.52$ & $8.07 \pm 2.15$ & $10.49 \pm 2.2$ & $15.91 \pm 1.19$ & $21.36 \pm 1.80$ & $36.31 \pm 3.48$ \\
\hline F6 & $5.55 \pm 0.94$ & $8.00 \pm 2.41$ & $17.24 \pm 0.7$ & $20.52 \pm 2.1$ & $24.75 \pm 1.3$ & $34.80 \pm 1.63$ & $44.40 \pm 1.30$ & $36.31 \pm 2.41$ \\
\hline F7 & $1.39 \pm 2.21$ & $4.34 \pm 2.08$ & $5.53 \pm 2.53$ & $9.07 \pm 1.64$ & $12.04 \pm 1.8$ & $17.94 \pm 2.07$ & $22.69 \pm 2.45$ & $36.31 \pm 1.31$ \\
\hline F8 & $1.86 \pm 3.32$ & $5.19 \pm 2.39$ & $8.26 \pm 2.56$ & $12.43 \pm 3.6$ & $14.95 \pm 2.8$ & $17.45 \pm 3.48$ & $21.35 \pm 2.73$ & $36.31 \pm 1.66$ \\
\hline
\end{tabular}

Table 9: The In vitro studies data of formulation of piroxicam.

\begin{tabular}{|l|l|l|l|l|l|l|l|}
\hline \multirow{2}{*}{ Formulation } & \multicolumn{7}{|c|}{ Time (min) } \\
\cline { 2 - 8 } & $\mathbf{4 8 0}$ & $\mathbf{6 0 0}$ & $\mathbf{7 2 0}$ & $\mathbf{8 4 0}$ & $\mathbf{1 4 4 0}$ & $\mathbf{1 8 0 0}$ & $\mathbf{2 1 6 0}$ \\
\hline F1 & $46.65 \pm 3.17$ & $57.08 \pm 3.8$ & $63.86 \pm 2.6$ & $73.3 \pm 2.97$ & $78.23 \pm 2.6$ & $87.34 \pm 1.29$ & $92.49 \pm 3.03$ \\
\hline F2 & $65.95 \pm 2.27$ & $69.19 \pm 2.7$ & $72.23 \pm 2.9$ & $77.54 \pm 2.5$ & $80.7 \pm 2.54$ & $89.87 \pm 3.56$ & $91.62 \pm 2.93$ \\
\hline F3 & $36.82 \pm 2.41$ & $47.97 \pm 2.4$ & $59.80 \pm 5.2$ & $71.94 \pm 5.5$ & $78.97 \pm 2.0$ & $88.17 \pm 3.99$ & $91.84 \pm 2.80$ \\
\hline F4 & $70.27 \pm 3.15$ & $73.24 \pm 2.0$ & $78.48 \pm 1.6$ & $82.75 \pm 1.6$ & $87.02 \pm 2.3$ & $87.04 \pm 2.34$ & $87.04 \pm 2.61$ \\
\hline F5 & $43.11 \pm 3.28$ & $53.68 \pm 3.5$ & $67.28 \pm 3.6$ & $78.18 \pm 5.6$ & $85.76 \pm 3.2$ & $85.80 \pm 3.01$ & $85.80 \pm 3.31$ \\
\hline F6 & $60.03 \pm 1.84$ & $67.35 \pm 1.1$ & $72.89 \pm 2.3$ & $76.48 \pm 2.4$ & $89.60 \pm 1.3$ & $95.82 \pm 2.70$ & $99.90 \pm 2.05$ \\
\hline F7 & $40.99 \pm 1.81$ & $52.26 \pm 1.9$ & $62.33 \pm 1.6$ & $73.28 \pm 2.4$ & $85.12 \pm 1.3$ & $88.13 \pm 1.26$ & $95.51 \pm 1.52$ \\
\hline F8 & $34.41 \pm 1.55$ & $39.44 \pm 1.9$ & $50.55 \pm 1.7$ & $61.97 \pm 3.0$ & $76.99 \pm 4.8$ & $84.27 \pm 3.49$ & $90.41 \pm 4.28$ \\
\hline
\end{tabular}

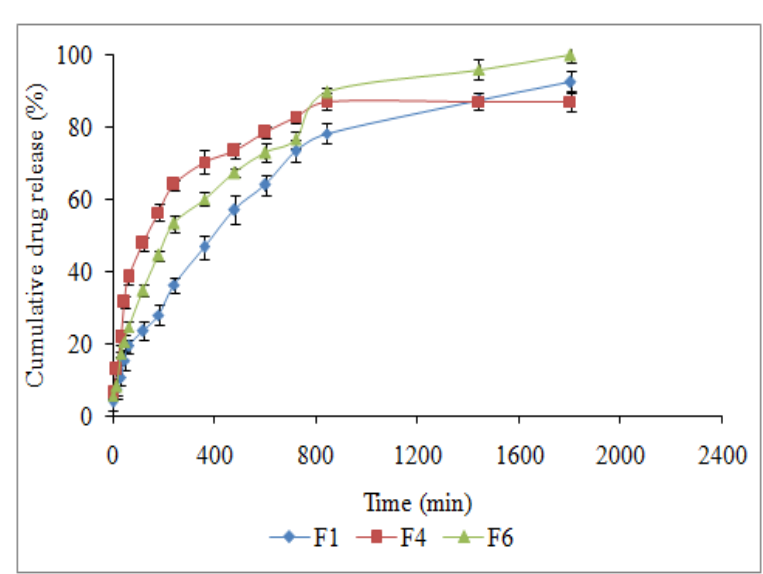

Figure 9: Plot of log cumulative \% drug remaining versus time across dialysis membrane for formulation F1, F4 and F6.

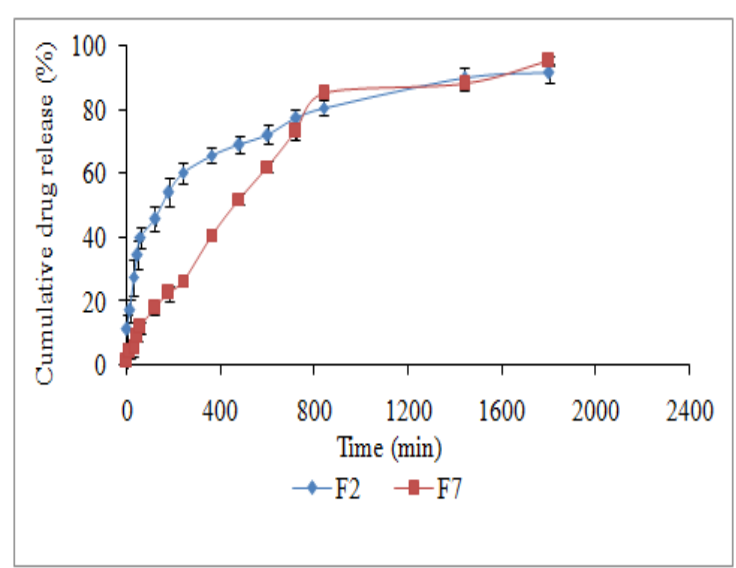

Figure 10: Plot of log cumulative \% drug remaining versus time across dialysis membrane for formulation F2 and F7. 


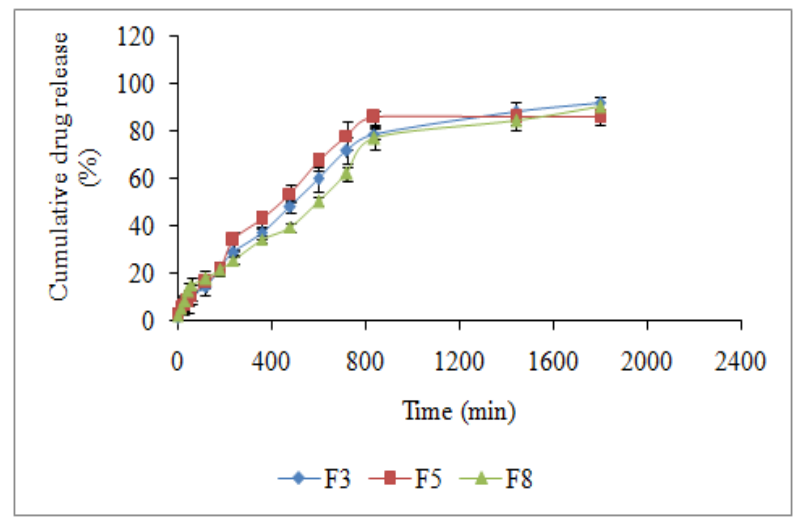

Figure 11: Plot of log cumulative $\%$ drug remaining versus time across dialysis membrane for formulation F3, F5 and F8.

\section{Drug Release Kinetic}

The in vitro dissolution data of various formulation was analyzed by fitting the obtained data into various kinetic model to explain the release kinetics. In the present study, it was observed that the in vitro dissolution profile of piroxicam from all the formulations followed zero order kinetics. The $\mathrm{n}$ value from drug release experiment for the formulations containing ethyl cellulose polymer alone had $\mathrm{n}$ value from 0.383 to 0.427 , indicated anomalous nonFickian type diffusion without swelling. In case of formulations containing HPMC alone or in combination with ethyl cellulose had values from 0.519 to 0.817 , indicating anomalous non-Fickian type diffusion with swelling.

Table 10: Results of kinetic studies of the dissolution data

\begin{tabular}{|l|l|l|l|l|l|}
\hline \multirow{2}{*}{ Formulation } & Zero order & First order & Higuchi's model & \multicolumn{2}{|l|}{ Peppas' model } \\
\cline { 2 - 6 } & $\mathrm{r}^{2}$ & $\mathrm{r}^{2}$ & $\mathrm{r}^{2}$ & $\mathrm{r}^{2}$ & $\mathrm{~N}$ \\
\hline F1 & 0.847 & 0.618 & 0.974 & 0.978 & 0.427 \\
\hline F2 & 0.718 & 0.518 & 0.917 & 0.934 & 0.383 \\
\hline F3 & 0.875 & 0.613 & 0.971 & 0.975 & 0.389 \\
\hline F4 & 0.607 & 0.422 & 0.944 & 0.887 & 0.519 \\
\hline F5 & 0.790 & 0.638 & 0.938 & 0.977 & 0.738 \\
\hline F6 & 0.794 & 0.553 & 0.964 & 0.957 & 0.572 \\
\hline F7 & 0.860 & 0.608 & 0.970 & 0.975 & 0.817 \\
\hline F8 & 0.910 & 0.646 & 0.983 & 0.968 & 0.707 \\
\hline
\end{tabular}

\section{CONCLUSION}

In conclusion we have developed formulation and development of transdermal patches of piroxicam. Transdermal patches increase the patient compliance over conventional dosage form. Transdermal medication delivers a steady infusion of a drug over an extended period of time. An equivalent therapeutic effect can be elicited via transdermal drug input with a lower daily dose of the drug than is necessary, e.g. the drug is given orally. The preformulation study were investigated and had similarity with official standard (I.P. 1996). The wavelength range determined using U.V. Spectrophotometer was found to be $336 \mathrm{~nm}$. HPMC, EC, PVP, Ethanol and PEG-400 were used in the formulation of transdermal patches.Eight batches of transdermal patches were prepared using different concentration HPMC, EC and PVP. Evaluation of each formulation was performed and formulation F6 was optimized best, because it had similarity with standard properties of transdermal patches. In-vitro release study provides information that transdermal patch is able to release $99.9 \%$ of drug.

\section{REFERENCE}

1. Arunachalam A, Karthikeyan, Vinay Kumar D, Prathap M, Sethuraman S, Ashutosh Kumar S and Manidipa S: Transdermal Drug Delivery System: A review. Current Pharma Research 2010; 1(1):70-81.

2. Saroha K, Yadav B and Sharma B: Transdermal patch: A discrete dosage form. International Journal of Current Pharma Research. 2011; 3:98-108.

3. Vinod KR, Sarvani P, Banji D and Teja BB: Transdermal drug delivery systemover coming challenges of popular drug delivery system. International Journal of Pharma World Research. 2010; 1:1-14.

4. Jain A, Mishra A, Nayak S and Soni V: Transdermal delivery of antihypertensive agents: A tabular update. International Journal of Drug Delivery. 2011; 3:1-13.

5. Sharma N, Agarwal G, Rana AC, Bhat Z and Kumar D: A Review: Transdermal drug delivery system: A tool for novel drug delivery system. International Journal of Drug Development and Research. 2011; 3:70-84.

6. Sampathkumar KP, Debjit B, Chiranjib B and Chandira RM: Transdermal drug delivery system-a novel drug delivery system and its market scope and opportunities. International Journal of Pharmacy and Bio Sciences. 2010; 1:1-21.

7. Patel D, Patel N, Parmar M and Kaur N: Transdermal drug delivery system: Review. International Journal of Biopharm and Toxicological Research. 2011; 1:61-80.

8. Baria $\mathrm{AH}$ and Patel RP: Formulation and evaluation considerations of transderma drug delivery system. International Journal of Pharmaceutical Research. 2011; 3:1-9.

9. Bhargava T, Ramchandani U, Shrivastava SK and Dubey PK: Current trends in NDDS with special reference to NSAIDs. International Journal of Pharmacy and Bio Sciences 2011; 2: 92 114.

10. Patel D, Sunita A. Chaudhary, Bhavesh Parmar, NikunjBhura. Transdermal drug delivery system: a review, vol-2, 2011, page no.78-88.

11. Baker W and Heller J."Material Selection for Transdermal Delivery Systems", In Transdermal Drug Delivery: Developmental Issues and Research Initiatives, J.Hadgraft and R.H.Guys, Eds. Marcel Dekker, Inc.,Newyork 1989 pp. 293311.

12. Baker W and Heller J."Material Selection for Transdermal Delivery Systems", In Transdermal Drug Delivery: Developmental Issues and Research Initiatives, J.Hadgraft and R.H.Guys, Eds. Marcel Dekker, Inc.,Newyork 1989 pp. 293311.

13. Wiechers J. Use of chemical penetration enhancers in Transdermal drug delivery- possibilities and difficulties. Acta pharm. $1992 ; 4: 123$.

14. Yamamoto T, Katakabe k, Akiyoshi K, Kan K and Asano T. Topical application of glibenclamide lowers blood glucose levels in rats. Diabetes res. Clin. Pract. 1990; 8:19-22.

15. Al- Khamis K, Davis S.S and Hadgraft J. Microviscosity and drug release from topical gel formulations. Pharm. Res. 1986; 3 : 214-217.

16. Anon. Transdermal delivery systems-general drug release standards. Pharmacopeial Forum, 1980; 14:3860-3865.

17. Mayorga P, Puisieux F and Couarraze G. Formulation study of a Transdermal delivery system of primaquine. Int. J. pharm. 1996; 132:71-79.

18. Deo M.R, SantV.P,Parekh S.R, Khopade A.J and Banakar U.V. Proliposome-based Transdermal delivery of levonorgestrel. Jour. Biomat. Appl. 1997; 12:77-88. 
19. Yan-yu X, Yun- mei S, Zhi-Peng C and Qi-nerg P. Preparation of silymarinproliposomes; A new way to increase oral bioavailability of silymarin in beagle dogs. Int. pharm. 2006; 319:162-168.

20. Crawford R.R and Esmerian O.K. Effect of plasticizers on some physical properties of cellulose acetate phthalate films. J. Pharm. Sci. 1997; 60:312- 314.
21. Keleb E, Sharma RK, Mosa EB, Aljahwi A-AZ. Transdermal Drug Delivery System - Design and Evaluation. International Journal of Advances in Pharmaceutical Sciences. 2010; 1:201211.

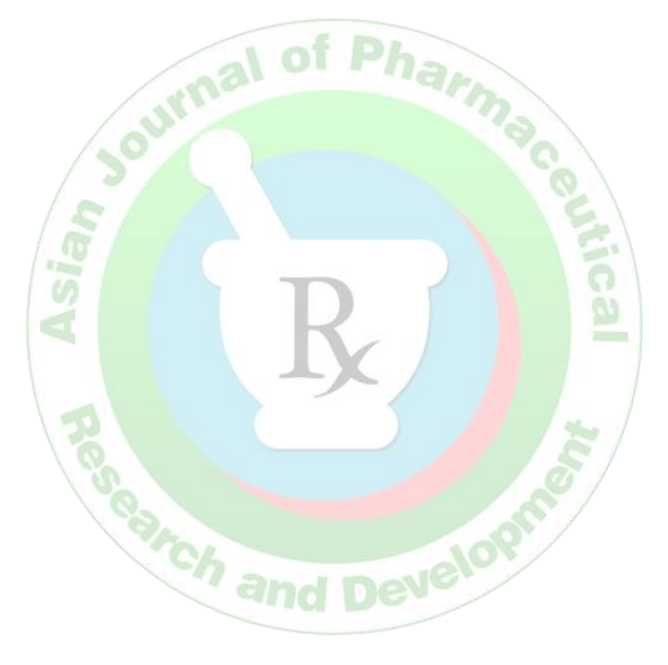

